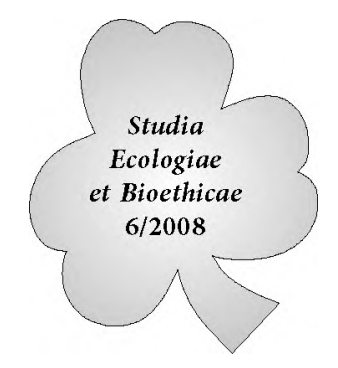

\title{
Historyczny rozwój programów działań na rzecz środowiska w Unii Europejskiej
}

Początki proekologicznych działan Wspólnoty Europejskiej datuje się na lata siedemdziesiąte XX wieku, co wiąże się przede wszystkim $\mathrm{z}$ intensywnym rozwojem społeczno-gospodarczym państw członkowskich, prowadzącym jednocześnie do wyraźnego wzrostu zanieczyszczenia środowiska w obrębie całej Wspólnoty. Choć w okresie tym nie stworzono jeszcze jednolitych i uregulowanych traktatowo zasad wspólnej polityki ekologicznej, to określone działania ochronne i stosowane w poszczególnych państwach członkowskich ekologiczne normy prawne, przyczyniły się do istotnych ograniczeń w dziedzinie wzajemnej wymiany handlowej. Konieczne stało się zatem podjęcie radykalnych kroków w celu zmiany zaistniałej sytuacji, powodującej częściowe zahamowanie rozwoju przedsiębiorczości i swobodnego prowadzenia działalności gospodarczej. W wyniku ostatecznego dostrzeżenia wagi problemu oraz dążenia do wskazania skutecznych metod jego niwelacji, szefowie krajów członkowskich Wspólnoty Europejskiej podczas szczytu zorganizowanego w Paryżu w czerwcu 1972 roku, powołując się na „harmonijny rozwój” jako jeden $z$ istotnych celów wspólnotowych, określonych w art. 2 \raktatu Rzymskiego, zobowiązali Komisję Europejską do opracowania konkretnych programów działań na rzecz ochrony środowiska ${ }^{1}$. Programy te już w założeniu miały stanowić wyznacznik kolejnych etapów rozwoju prawa ekologicznego Unii Europejskiej, określający priorytety oraz cele, ku którym zmierza polityka ochronna Wspólnot, a ich praktyczną realizację zaplanowano w odgórnie ustalonym i określonym ścisłymi ramami przedziale czasowym.

Pierwszy z omawianych programów obejmował swym zasięgiem lata 1973$-1975^{2}$, a jego podstawowym założeniem było ogólne zaprojektowanie i wdroże-

Polityka ochrony środowiska w Unii Europejskiej, ABC Unii Europejskiej. Opracowania wydane przez Przedstawicielstwo Komisji Europejskiej w Polsce w latach 1999-2004, Leograf GroupKrzysztof Kluk, lipiec 2004, s. 1.

2 Warto zauważyć, iż wedle niektórych źródeł początek realizacji I Środowiskowego Programu Działania przypada już na rok 1972, por. FIEDOR B. (red.): Dostosowanie polskiego prawa i regu- 
nie standardów jakości środowiska oraz produktów i procesów na płaszczyźnie wspólnotowej, przy czym pod pojęciem tychże jakości rozumiano zespół określonych wymagań, które muszą być spełnione w danym czasie, obecnie lub w przyszłości, w odniesieniu do konkretnego środowiska lub jego części. Wspólnotowa działalność proekologiczna skoncentrowała się wówczas głównie na dążeniu do neutralizacji źródeł zanieczyszczeń, podejmowaniu działań zapobiegawczych oraz likwidacji szkód w środowisku (włącznie ze stosowaniem kar dla sprawców degradacji świata przyrodniczego oraz zmuszaniem ich do pokrywania kosztów spowodowanych przez siebie szkód) $)^{3}$. W obrębie I Programu stworzona została zatem strategia kontroli zanieczyszczeń oraz wstępnie omówiono naczelne zasady unijnej polityki proekologicznej, wśród których najważniejsze miejsce zajęły: zasada „zanieczyszczający płaci” oraz zasada zapobiegania. Sformułowano w nim ponadto jakości środowiska dotyczące określonych kategorii korzystania z wody, w szczególności w zakresie rybołówstwa i zaopatrzenia ludności w wodę, a także te, które odnosiły się do wody przeznaczonej do kąpieli, zaopatrzenia rolnictwa i przemysłu spożywczego w zasoby wodne oraz wody wykorzystywanej w różny sposób na cele związane $\mathrm{z}$ rekreacją.

Kolejny z opracowanych programów, czyli Program II, został wyznaczony do wykonania na przestrzeni lat 1976-1981 i stanowił on kontynuację realizacji zadan, określonych w I Środowiskowym Programie Działania, które jednocześnie zostały dzięki niemu zaktualizowane i rozszerzone ${ }^{4}$. W jego ramach ustalono w zarysie priorytety, dotyczące konkretnych sfer polityki ochronnej oraz poszczególnych dziedzin gospodarki, obejmujących swym zasięgiem w szczególności ochronę powietrza i wód powierzchniowych. W programie tym skoncentrowano się przede wszystkim na problematyce racjonalnego gospodarowania zasobami przyrodniczymi, zmniejszeniu zanieczyszczeń, ochronie flory i fauny oraz ogólnej poprawie stanu środowiska. Dodatkowo zaakcentowano w nim rolę przeobrażeń technologicznych i strukturalnych w gospodarce, uznając je za istotną formę wspierania działalności proekologicznej. W tym okresie po raz pierwszy zgłoszony został plan wprowadzenia działań ochronnych w obrębie wód morskich. Jako nowa dziedzina unijnych przedsięwzięć pojawiła się również walka $\mathrm{z}$ hałasem, o czym zadecydowały przede wszystkim względy ekonomiczne ${ }^{5}$.

lacji ekologicznych do rozwiąań Unii Europejskiej. Koszty i strategia., Wydawnictwo Ekonomia i Srodowisko, Wrocław-Białystok 1999-2000, s. 18.

3 Czachór Z.: Slowniczek Europejski. Unia Europejska, Warszawa 1996, s. 21.

4 Borys冈. (red.): Wskaźniki ekorozwoju, Wydawnictwo Ekonomia i Srodowisko, Białystok 1999, s. 106.

5 Wysokińska Z., Witkowska J.: Integracja Europejska. Dostosowania w Polsce w dziedzinie polityk, Polskie Wydawnictwo Ekonomiczne, Warszawa 2004, s. 167. 
Analizując znaczenie I i II Programu Działań na rzecz środowiska należy podkreślić, iż dzięki nim opracowane zostały naczelne zasady dotyczące unijnej polityki proekologicznej, wyznaczające ogólne ramy wspólnotowych działań ochronnych, które następnie znalazły swe zastosowanie przy wprowadzaniu w życie kolejnych programów. Do zasad takich zaliczono:

a) zasadę unikania takiego korzystania z przyrody, które wywołuje nadmierne naruszenie równowagi biologicznej;

b) zasadę, zgodnie z którą działalność na obszarze jednego państwa nie może wywoływać degradacji środowiska w innym kraju;

c) zasadę „Zanieczyszczający płaci”, a więc złożenie ciężaru ponoszenia skutków degradacji środowiska na barki sprawcy tejże degradacji;

d) zasadę subsydiarności (pomocniczości), w myśl której wszelkie instrumenty ochronne winny być wykorzystywane na najbardziej „właściwym poziomie”, a więc muszą one być miarodajne do rodzaju zanieczyszczenia, konieczności zastosowania danego działania oraz obszaru geograficznego wymagającego w danej sytuacji ochrony;

e) zasadę wspomagania przez Wspólnotę Europejską i jej członków wszelkiego rodzaju działań proekologicznych zarówno w skali międzynarodowej, jak i globalnej, wskutek podejmowania konkretnych kroków w tym zakresie na forum organizacji międzynarodowych;

f) zasadę, zgodnie z którą lepiej jest zapobiegać niż leczyć (istotnym jest, że jej najpełniejsze rozwinięcie miało miejsce dopiero w trakcie realizacji IV Programu Środowiskowego);

g) zasadę koordynacji krajowych programów ochronnych na rzecz środowiska w oparciu o wspólne koncepcje mające charakter długoterminowy oraz harmonizacji krajowej polityki proekologicznej w ramach działań tożsamych dla całej Wspólnoty, a nie zaś takich, które odbywają się w oderwaniu od niej;

h) zasadę rozwoju i pogłębiania wiedzy naukowej, służącej prowadzeniu skuteczniejszej działalności ochronnej na rzecz środowiska;

i) zasadę, w myśl której państwa członkowskie przy realizacji swej proekologicznej polityki winny brać pod uwagę istotne interesy krajów rozwijających się;

j) zasadę uznającą ochronę środowiska za obowiązek każdego człowieka, co niesie ze sobą potrzebę wdrażania edukacji w tej dziedzinie;

k) zasadę, zgodnie z którą wpływ danych działań na środowisko winien być zauważany na możliwie najwcześniejszym etapie podejmowania konkretnych decyzji ${ }^{6}$.

6 KozŁowski S.: Ekorozwój. Wyzwanie XXI wieku, Wydawnictwo Naukowe PWN, Warszawa 2000, s. 158-159. 
Następny ze Środowiskowych Programów Działania, a więc III Program, zrealizowano w latach 1982-1986. Objął on swym zasięgiem ochronę powietrza i wód, postępowanie z niebezpiecznymi materiałami chemicznymi, gospodarkę odpadami, rozwój technologii ochrony środowiska oraz hałas i wibracje, dla których ustalono ścisłe priorytety oraz wskazano na konkretne metody ich realizacji. W czasie obowiązywania III Programu nastąpił intensywny rozwój działań związanych zarówno z kształtowaniem systemu opłat ekologicznych, jak i standardami jakości środowiska, których definicję sformułowano już w trakcie obowiązywania I Programu. W okresie tym opracowano także konkretne definicje dwóch istotnych zasad ekologicznych, a więc zasady zapewnienia przyszlym pokoleniom możliwości korzystania z zasobów przyrodniczych oraz reguły trwałości kapitału naturalnego, które zaliczono do naczelnych gwarancji rozwoju gospodarczego, będącego jednocześnie ogólnym wyznacznikiem postępu cywilizacji ${ }^{7}$. Zasady te miały stanowić najważniejszy cel polityki proekologicznej Wspólnot, odnoszący się bezpośrednio do koncepcji zrównoważonego rozwoju. W tym czasie dokonano także rozszerzenia zakresu dotychczasowego pojmowania terminu „ochrona środowiska" poprzez objęcie nim również problematyki odnoszącej się do zagospodarowania przestrzennego. Warto zauważyć, iż w dziedzinie unormowań prawnych na plan pierwszy wysunęło się wówczas dążenie do umocnienia pozycji i skuteczności wspólnotowego ustawodawstwa ochronnego, czego wyrazem było zaopatrzenie Komisji Europejskiej w uprawnienia do implementacji europejskiego prawa ekologicznego do porządków prawnych poszczególnych państw członkowskich.

Dalszy rozwój unijnej działalności ochronnej związany był ściśle z wprowadzeniem w życie kolejnego - IV-go Programu, który został przyjęty do realizacji w latach 1987-1991. W jego ramach przewidziano wyraźne rozszerzenie możliwości publicznego dostępu do informacji, dotyczących stanu środowiska i niebezpieczeństw towarzyszących korzystaniu z zasobów naturalnych oraz opracowano nowoczesne standardy emisyjne w zakresie poszczególnych elementów środowiskowych. Wdrożenie wspomnianego programu spowodowało wyraźne przesunięcie proekologicznej polityki wspólnotowej z ukierunkowania na niwelację skutków zanieczyszczeń w stronę działalności prewencyjnej ${ }^{8}$. Stąd też naczelną dziedziną unijnych wysiłków ochronnych stało się wówczas dążenie do zmniejszenia skażenia powietrza i wód substancjami szkodliwymi, ze szczególnym uwzględnieniem zapobiegania powstawaniu nowych źródeł zanieczyszczeń. Ponadto wzrosło zastosowanie dla celów proekologicznych instrumentów o charakterze prawno-finansowym, a wśród nich przede wszystkim opłat, podatków,

Borys \. (red.): Wskaźniki ekorozwoju, op. cit., s. 106.

8 Polityka ochrony środowiska w Unii Europejskiej, op. cit., s. 2. Por. Aвramczyк: Polityka Ekologiczna Unii Europejskiej, Aura z 1997 r., nr 5. 
ubezpieczeń ekologicznych oraz dotacji i subwencji. W okresie tym miał miejsce intensywny rozwój systemów, dotyczących przepływu informacji i monitoringu, powiązanych ściśle z bieżącym zanieczyszczeniem środowiska (głównie z emisją różnorodnych zanieczyszczeń i ich koncentracją), a także $z$ nakładami finansowymi na rzecz działań ochronnych. Nową dziedziną wspólnotowej aktywności stała się wówczas biotechnologia. Nastąpił także wzrost zainteresowania problematyką, odnoszącą się do ochrony środowiska miejskiego, co w 1990 roku zaowocowało przyjęciem przez Komisję Europejską tzw. Zielonej Karty w sprawie środowiska miejskiego. Realizacja IV Programu zainicjowała ponadto pojawienie się tzw. ochrony zintegrowanej. Oznaczało to, iż wszelkie prace, służące wspieraniu działalności proekologicznej, traktowane uprzednio jako element dodatkowy, stały się zintegrowaną częścią całego procesu produkcji.

Uprawnienia Wspólnoty Europejskiej w zakresie ochrony środowiska zostały określone w Jednolitym Akcie Europejskim, na mocy którego uzyskała ona legitymację prawną dla działań proekologicznych. Akt ten uchwalono w 1986 roku, a wszedł on w życie 1 lipca 1987 roku. Na jego podstawie wprowadzono do \raktatu Rzymskiego nowy tytuł VII - „Środowisko naturalne”. Umieszczone we wskazanym tytule artykuły $\mathrm{nr}$ 130R-130区 (wedle wersji skonsolidowanej noszące numery 174-176) podkreśliły dominującą rolę prewencji w zakresie ochrony środowiska oraz wprowadzily zorganizowany system zasad dotyczących tej materii. Wśród nich wymieniono zasadę subsydiarności (pomocniczości), zgodnie z którą Wspólnota winna podejmować działania związane $z$ polityką proekologiczną $\mathrm{w}$ stopniu, $\mathrm{w}$ jakim cele wyszczególnione w tytule VII JAE mogą zostać osiągnięte $z$ lepszym rezultatem na poziomie wspólnotowym niż na poziomie indywidualnych państw członkowskich ${ }^{9}$. Obok zasady subsydiarności wskazano również na: zasadę naprawy szkód w obrębie środowiska (przede wszystkim już u ich źródła), regułę podejmowania możliwych środków ostrożności oraz zasadę odpowiedzialności sprawcy za szkodliwe zmiany w środowisku (tzw. zasada „zanieczyszczający płaci” - polluter pays principle - PPP). Należy zauważyć, iż JAE odegrał niewątpliwie bardzo ważną rolę w zakresie formowania podstaw prawnych unijnej działalności na rzecz ochrony środowiska. Wprowadzone na jego podstawie przeobrażenia uczyniły bowiem politykę proekologiczną sprawą równie istotną, jak sam rozwój społeczno-gospodarczy Wspólnot. Dobitny wyraz takiego stanu rzeczy zamieszczony został następnie w \raktacie z Maastricht, którego kontynuację i rozszerzenie odnajdujemy w \raktacie Amsterdamskim z dnia 2 października 1997 roku, zmieniającym częściowo Draktat o Unii Europejskiej i uznającym postanowienia dotyczące zrównoważonego rozwoju za zadania przeznaczone do realizacji dla całej Unii Europejskiej ${ }^{10}$.

9 Art. 130R ust. 4 JAE, http://www.polskiejutro.com/pdf/Jednolity_Akt_Europejski.doc.

10 Kistowski M.: Regionalny model zrównoważonego rozwoju i ochrony środowiska Polski a strategie rozwoju województw, Uniwersytet Gdański, Bogucki Wydawnictwo Naukowe, GdańskPoznań 2003 s. 23. 
Ważnym krokiem na drodze proekologicznych przeobrażeń, rozpoczętym w okresie obowiązywania IV Programu było także podkreślenie negatywnego oddziaływania transportu na środowisko naturalne, co doprowadziło do opracowania przez Dyrekcję Generalną Komisji Europejskiej w 1992 roku tzw. Zielonej Księgi, poświęconej temu problemowi ${ }^{11}$.

Istotną konsekwencję wprowadzania w życie postanowień IV Programu stanowiło ponadto wydanie Rozporządzenia Rady EWG/1210/90 z dnia 7 maja 1990 roku, odnoszącego się do europejskiej sieci obserwacji i informacji o ochronie środowiska oraz Europejskiej Agencji ds. Środowiska ${ }^{12}$, która pełni funkcję ponadnarodowej inspekcji, zajmującej się kontrolą procesu implementacji prawa wspólnotowego do wewnętrznych porządków prawnych państw członkowskich. Kolejny ze Środowiskowych Programów Działania, a więc Program V, został wyznaczony początkowo do realizacji w latach 1993-1997, a następnie przedłużono go do 2000 roku. Program ten określono mianem „W stronę zrównoważonego rozwoju" (囚owards Sustainability), a za naczelne dziedziny wymagające bliższego zainteresowania w czasie jego wdrażania uznano: energetykę, transport, przemysł, rolnictwo i turystykę jako sektory wywierające istotny wpływ na środowisko, a jednocześnie odrywające zasadniczą i niezaprzeczalną rolę w procesie rozwoju gospodarczego (było to przejawem szczególnej troski o „ekologiczną jakość" tychże dziedzin). Głównym zadaniem w tym okresie stało się zatem dążenie do osiągnięcia równowagi pomiędzy rozwojem cywilizacyjnym, a utrzymaniem ekonomicznych i pozackonomicznych walorów i zasobów środowiska, traktowanych jako podstawowe wyzwanie zarówno dla Unii Europejskiej, jak i całego świata ${ }^{13}$. Przyjęcie takiego stanowiska oznaczało jednocześnie, że naczelne założenia V Programu winny pokrywać się z regułami określonymi programem Agenda 21, który opracowano w 1992 roku w trakcie Konferencji Narodów Zjednoczonych „Środowisko i Rozwój” w Rio de Janeiro ${ }^{14}$.

W ramach V Środowiskowego Programu Działania określono podstawowe wyznaczniki niezbędne do skutecznej realizacji strategii zrównoważonego rozwoju, wśród których na pierwszym planie znalazło się:

11 Kawecka-Wyrzykowska E., Synowiec E.: Europejska Integracja Polski z Unia Europejską, Warszawa 1997, s. 224.

12 Patrz Rozporządzenie Rady (EWG) 1210/90 z dnia 7 maja 1990 roku w sprawie ustanowienia Europejskiej Agencji Środowiska oraz Europejskiej Sieci Informacji i Obserwacji Środowiska, Dz.Urz. WE L 120 z 11.05.1990, s. 1-6. Należy tu wspomnieć, iż omawiane rozporządzenie zostało znowelizowane na mocy Rozporządzenia Rady (WE) 933/1999 z dnia 29 kwietnia 1999 roku zmieniającego Rozporządzenie Rady (EWG) 1210/90 z dnia 7 maja 1990 roku w sprawie ustanowienia Europejskiej Agencji Środowiska oraz Europejskiej Sieci Informacji i Obserwacji Środowiska, Dz.Urz. WE L 117 z 05.05.1999, s. 1-4.

13 Fiedor B. (red.): Dostosowanie polskiego prawa..., op. cit., s. 20.

14 Kociszewski K.: Rozwój zrównoważony (ekorozwój) - definicja, podstawowe pojęcia, zastosowanie, Akademia Ekonomiczna we Wrocławiu, http://www.ecp.wroc.pl/msp/kociszewskil.pdf 
a) przyjęcie zasady, iż konsumpcja dóbr w obrębie jednego pokolenia nie może przyczyniać się do poważnego wzrostu strat poniesionych przez kolejne generacje zamieszkujące Ziemię;

b) uznanie, że skuteczność działalności człowieka oraz społeczno-gospodarczy rozwój świata są ściśle uzależnione od stanu środowiska i jego zasobów, a także zapewnienia im należytej ochrony;

c) przyjęcie zasady współodpowiedzialności oraz zasady podejścia zapobiegawczego;

d) propagowanie racjonalnego korzystania $\mathrm{z}$ zasobów i surowców, przepływających przez gospodarkę, ze względu na przyjęcie założenia, że ich wielkość jest stała ${ }^{15}$.

Ponadto podczas wdrażania V Programu, odmiennie niż odbywało się to dotychczas, doprowadzono do wyraźnego zmniejszenia wykorzystania nakazów i zakazów do celów proekologicznych, a w ich miejsce skoncentrowano się na zastosowaniu instrumentów typowo proceduralnych oraz narzędzi pośrednich takich jak: polityka informacyjna, współuczestnictwo, podatki ekologiczne oraz procedury, mające za zadanie pobudzić podmioty zajmujące się prowadzeniem szeroko rozumianej działalności gospodarczej do podejmowania środków ochronnych na rzecz środowiska. Istotne znaczenie odgrywały w tym zakresie przede wszystkim narzędzia ekonomiczne oraz fiskalne, a w tym zwłaszcza:

- opłaty i podatki zasilające $\mathrm{w}$ dużej mierze fundusze wykorzystywane do likwidowania szkód ekologicznych;

- zachęty podatkowe jako bodźce do formowania określonych modeli konsumpcyjnych i wzorców zachowań ( $w$ tym $\mathrm{m}$. in. podatek od benzyny ołowiowej i bezołowiowej) ${ }^{16}$.

W ramach V Programu po raz pierwszy rozszerzony został katalog bezpośrednich adresatów konkretnych zadań, które zostały wyznaczone do realizacji w trakcie jego obowiązywania, skutkiem czego skierowano go ostatecznie także do organizacji konsumenckich, przedstawicieli przedsiębiorstw i organizacji pozarządowych.

W tym czasie Wspólnota zacieśniła swą współpracę w zakresie działań proekologicznych z państwami kandydującymi do członkostwa w Unii Europejskiej oraz istotnie rozwinęła i umocniła swą działalność ochronną na szczeblu ogólnoświatowym. Odzwierciedleniem tego było przede wszystkim skoncentrowanie się na prowadzeniu wspólnej polityki na rzecz środowiska, której podstawowe elementy stanowiły: wdrażanie wspólnego prawa europejskiego i postępu naukowo-technicznego, konsekwentna realizacja zasad jednolitego rynku, wywieranie wpływu

\footnotetext{
5 Kistowski M.: Regionalny model zrównoważonego rozwoju..., op. cit., s. 23; Równy K.: Koncepcja zrównoważonego rozwoju w prawie wspólnotowym i polskiej rzeczywistości (Zarys najważniejszych zagadnień wyjściowych), Przegląd Prawa Europejskiego z 2000 r., nr 2.

16 Borys 囚. (red.): Wskaźniki ekorozwoju, op. cit., s. 108.
} 
na kształtowanie świadomości społecznej przyjaznej środowisku, tworzenie funduszy ekologicznych oraz przemiany w zakresie wzorców konsumpcyjnych ${ }^{17}$.

W okresie obowiązywania V Środowiskowego Programu Działania zrezygnowano ze stosowanego uprzednio w obrębie ochrony środowiska podejścia wertykalnego (sektorowego), dotyczącego skutków związanych z wpływem wywieranym przez człowieka na poszczególne składniki przyrody, na rzecz tzw. podejścia horyzontalnego, uwzględniającego wszelkie możliwe przyczyny zanieczyszczeń, a więc służącego kompleksowej ochronie wszystkich elementów składowych środowiska.

Warto także zauważyć, iż przyjęcie do realizacji omawianego programu zbiegło się w czasie z pełnym uznaniem istotnych związków, zachodzących pomiędzy działalnością na rzecz ochrony środowiska, a dążeniem do trwałych przemian społeczno-ekonomicznych nie tylko w obrębie samej Wspólnoty, ale również w skali globalnej. Wyrazistym przejawem takiego stanowiska są unormowania zawarte w \raktacie z Maastricht, który działalność proekologiczną uznaje za równoważną $\mathrm{z}$ nadrzędnym celem wspólnotowym, a więc zagwarantowaniem i osiągnięciem pełnego rozwoju gospodarczego. Umocnienie oraz potwierdzenie regulacji z Maastricht zostało następnie zamieszczone w هraktacie Amsterdamskim, na mocy którego wprowadzono do \raktatu o WE nowy artykuł (nr $6 \mathrm{w}$ wersji skonsolidowanej). Zgodnie z nim wymogi ochrony środowiska muszą być uwzględniane podczas ustalania i realizacji wszelkich elementów składowych polityki Wspólnoty, a zwłaszcza takich, które mają na celu trwały rozwój ${ }^{18}$.

Ostatni z przygotowanych programów, czyli VI Środowiskowy Program Działania został zaproponowany do zrealizowania w latach 2001-2010 i funkcjonuje pod nazwą „Środowisko 2010: Nasza przyszłość zależy od naszego wyboru” (Environment 2010: Our Future, Our Choice). Jego opracowanie i publikacja miały miejsce w styczniu 2001 roku w wyniku przeprowadzenia ogólnej oceny Programu V, która dokonana została przez Komisję Europejską już w 1999 roku. Nastąpiło to po sporządzeniu przez Europejską Agencję Środowiska raportu na temat stanu środowiska, w którym poddano krytyce skuteczność unijnej polityki proekologicznej, głównie z uwagi na nieefektywne wdrażanie w państwach członkowskich wspólnotowych dyrektyw, dotyczących działań ochronnych. Z uwagi na powyższe w VI Programie założono zwiększenie wpływu, wywieranego na kraje członkowskie w celu zagwarantowania sprawniejszej implementacji obowiązujących przepisów proekologicznych ${ }^{19}$.

17 Radziejowski J., Niesy to G., Jezionski J.: Integracja europejska a ochrona środowiska, Fundacja Rozwój SGGW, Warszawa 2002, s. 57.

18 Polityka ochrony środowiska w Unii Europejskiej, op. cit., s. 2.

19 Wojt kowska-Łodej G.: Polityka ochrony środowiska, (w:) Kawecka-Wyrzykowska E., Synowiec E. (red.) Unia Europejska, t. I, Instytut Koniunktur i Cen Handlu Zagranicznego, Warszawa 2004, s. 269. 
Za naczelne dziedziny w zakresie wspierania ochrony środowiska Komisja uznała w tym czasie przede wszystkim działania następującego rodzaju:

a) racjonalne gospodarowanie zasobami naturalnymi oraz właściwe zarządzanie odpadami - w tym obrębie wysunięto trzy podstawowe postulaty, a więc: zrównoważone wykorzystywanie odnawialnych i nieodnawialnych zasobów naturalnych (a w tym także dążenie do oddzielenia tego wykorzystania od samego procesu wzrostu gospodarczego w wyniku zwiększenia efektywnego korzystania ze wskazanych zasobów), odmaterializowanie gospodarki oraz ograniczenie produkcji odpadów ${ }^{20}$. Uznano, iż omawiane procesy winny następować $\mathrm{m}$. in. poprzez zastosowanie zintegrowanej polityki produktowej, poszukiwanie skutecznych procesów recyklingu oraz sformułowanie i wdrażanie regionalnych programów leśnych i certyfikowanie lasów na potrzeby zrównoważonego zarządzania zasobami leśnymi. W zakresie racjonalnego gospodarowania odpadami wysunięto ponadto propozycję wzrostu bezpieczeństwa odpadów oraz dążenie do neutralizacji tych odpadów jak najbliżej miejsca ich powstania, pod warunkiem jednak, że nie pozostaje to w sprzeczności z prawem unijnym ${ }^{21}$;

b) zagwarantowanie właściwego wpływu środowiska na ludzkie zdrowie poprzez wprowadzenie bardziej restrykcyjnych norm w tym zakresie, przy czym istotne jest, że takie działania mają zapewnić uzyskanie odpowiedniego stanu środowiska, w którego obrębie zarówno hałas, jak i zanieczyszczenie wody i powietrza chemikaliami i pestycydami, nie będą zagrażać człowiekowi. Ponadto dbałość o zdrowie, ujmowane znacznie szerzej niż tylko jako brak choroby czy też kalectwa ${ }^{22}$, niesie ze sobą potrzebę opracowania i praktycznego zastosowania zasady ostrożności oraz zasady zapobiegania, które winny być wykorzystywane zwłaszcza w stosunku do kręgów najbardziej narażonych, a więc względem dzieci oraz osób w podeszłym wieku ${ }^{23}$;

c) przeciwdziałanie zmianom klimatycznym, a w tym przede wszystkim efektowi cieplarnianemu, poprzez ustabilizowanie poziomu gazów cieplarnianych, których szkodliwe wydzielanie związane jest głównie z rozwojem komunikacji lotniczej i drogowej, spalaniem paliwa kopalnego w elektrowniach, intensyfikacją procesów produkcyjnych oraz powstawaniem nowych wysypisk odpadów ${ }^{24}$. Istotne jest przy tym, iż w myśl regulacji zawartych w Protokole z Kioto planowane zmniejszenie emisji gazów cieplarnianych w obrębie Unii

20 Kistowski M.: Regionalny model zrównoważonego rozwoju..., op. cit., s. 24.

21 Wysokińska Z., Witkowska J.: Integracja Europejska..., op. cit., s. 170.

22 Warto bowiem zauważyć, iż pod pojęciem tym w miejsce jedynie braku oznak choroby lub ułomności, rozumie się także stan kompletnego fizycznego, umysłowego i społecznego dobrego samopoczucia. Patrz KozŁowski S.: Przyszłość ekorozwoju, Wydawnictwo KUL, Lublin 2005, s. 404.

23 Ibidem.

24 Wojtkowska-Łodej G.: Polityka ochrony środowiska, op. cit., s. 269. 
Europejskiej winno wynieść w latach 2008-2012 około 8\% względem ich poziomu ustalonego w roku $1999^{25}$;

d) ochrona przyrody i bioróżnorodności poprzez wzrost liczby obszarów uznanych za chronione (w obrębie których winny znaleźć się także obszary morskie), ograniczenie liczby gatunków zmodyfikowanych genetycznie wprowadzanych w świat przyrodniczy, odtworzenie naturalnych systemów w rejonach, w których takie działania okażą się niezbędne oraz zwalczanie zanieczyszczenia i erozji gleb.

Ustalenie powyższych priorytetów dotyczących polityki ochronnej, związane było ściśle z dążeniem do wypracowania konkretnych rozwiązań praktycznych w tym zakresie. Stąd też uznano, iż osiągnięciu właściwych rezultatów i poprawie istniejącego stanu rzeczy w wyszczególnionych powyżej dziedzinach służyć ma pięć podstawowych metod, traktowanych jako cele strategiczne VI Programu. Zaliczono do nich:

a) zacieśnioną współpracę z konsumentami i organizacjami biznesowymi, mającą zapewnić odnalezienie najbardziej optymalnych rozwiązań;

b) zagwarantowanie skutecznego wprowadzania $w$ życie sformułowanych uprzednio przepisów prawa ekologicznego - tu istotne znaczenie ma przede wszystkim dążenie do zaostrzenia sankcji karnych przewidzianych za popełnienie przestępstw przeciwko środowisku;

c) uwzględnianie potrzeb ochrony środowiska we wszystkich płaszczyznach wspólnotowej polityki, w ramach czego przewidziano między innymi dalszy rozwój wskaźników wykorzystywanych przy monitorowaniu i raportowaniu postępu dotyczącego działań na rzecz integracji problematyki ochrony środowiska $z$ innymi unijnymi politykami sektorowymi;

d) rozwój bardziej świadomego podejścia względem wykorzystywania gruntów z perspektywy ich roli w zakresie działań proekologicznych, co zakłada przede wszystkim wzrost znaczenia planowania przestrzennego i zagospodarowania terenu, zwłaszcza na obszarach nadmorskich i gruntach miejskich, gdzie obserwuje się największe rozmiary negatywnego wpływu działalności człowieka ${ }^{26}$;

e) zapewnienie wszystkim obywatelom Unii lepszej i ogólnie dostępnej informacji o stanie środowiska oraz ich uczestnictwo w procesach decyzyjnych dotyczących tej materii.

Oceniając znaczenie VI Programu, warto zauważyć, iż program ten ma pełnić przede wszystkim rolę istotnego elementu całościowej polityki unijnej, zmierzającej do wyraźnej poprawy jakości środowiska i standardów życia w obrębie Wspólnoty oraz służącej wdrażaniu zasady zrównoważonego rozwoju w jej społecznym i gospodarczym wymiarze.

${ }^{25}$ KozŁowski S.: Przyszlość..., op. cit., s. 402.

26 Ibidem, s. 400-401. 
Na zakończenie ogólnej analizy dotyczącej historycznego rozwoju programów działań na rzecz ochrony środowiska w Unii Europejskiej, należy podkreślić wagę problematyki proekologicznej w prawodawstwie wspólnotowym, którą dobitnie uwypuklił projekt \raktatu ustanawiającego Konstytucję dla Europy. Akt ten już w części I, określając cele Unii wskazał, że trwały rozwój Europy warunkowany jest m.in. wysokim poziomem ochrony i poprawy jakości środowiska naturalnego ${ }^{27}$, przy czym istotne jest, iż w dalszych postanowieniach kompetencje do działań w tym obszarze zostały podzielone pomiędzy Unię a państwa członkowskie ${ }^{28}$. Część II 『raktatu zatytułowana - Karta Praw Podstawowych Unii, również odnosi się do zagadnień ochrony środowiska, czego przejawem jest art. II-97 stanowiący, że zapewnienie wysokiego poziomu ochrony środowiska i poprawa jego jakości muszą być zintegrowane z politykami Unii i realizowane zgodnie z zasadą stałego rozwoju. Postanowienia te zostały dalej rozwinięte i uszczegółowione w Części III Konstytucji, a głównie w art. III-233 i III-234, które określają cele i wyznaczniki działań Unii w sferze ochrony środowiska oraz tryb tworzenia prawodawstwa w tym zakresie. Pomimo, iż \raktat w zaprezentowanym kształcie nie wejdzie w życie, to wyeksponowanie istotnej roli zagadnień proekologicznych w projekcie najważniejszego aktu Unii Europejskiej dobitnie ukazuje ewolucję, jaka dokonała się w tym zakresie na przestrzeni kilkudziesięciu lat istnienia Wspólnot.

\section{LITERATURA}

Borys \. (red.): Wskaźniki ekorozwoju, Wydawnictwo Ekonomia i Środowisko, Białystok 1999.

CzAchór Z.: Slowniczek Europejski. Unia Europejska, Warszawa 1996.

FIEDor B.(red.): Dostosowanie polskiego prawa i regulacji ekologicznych do rozwiazań Unii Europejskiej. Koszty i strategia, Wydawnictwo Ekonomia i Środowisko, Wrocław-Białystok 1999-2000.

Kawecka-Wyrzy Kowska E., Symonowiec E.: Europejska Integracja Polski z Unią Europejską, Warszawa 1997.

KIstowski M.: Regionalny model zrównoważonego rozwoju i ochrony środowiska Polski a strategie rozwoju województw, Uniwersytet Gdański, Bogucki Wydawnictwo Naukowe, Gdańsk-Poznań 2003.

KozŁowski S.: Ekorozwój. Wyzwanie XXI wieku, Wydawnictwo Naukowe PWN, Warszawa 2000.

KozŁowski S.: Przyszlość ekorozwoju, Wydawnictwo KUL, Lublin 2005.

Polityka ochrony środowiska w Unii Europejskiej, ABC Unii Europejskiej. Opracowania wydane przez Przedstawicielstwo Komisji Europejskiej w Polsce w latach 1999-2004, Leograf GroupKrzysztof Kluk, lipiec 2004.

RADZIEJOWSKI J., NiEsyto G., JEZIORSKI J.: Integracja europejska a ochrona środowiska, Fundacja Rozwój SGGW, Warszawa 2002.

27 Patrz art. I-3 ust. 3 囚raktatu ustanawiającego Konstytucję dla Europy, Dz. Urz. C 310 z 16.12.2004.

28 Por. art. I-14 ust. 2 pkt e omawianego traktatu. 
Wojt kowska-Łodej G.: Polityka ochrony środowiska, (w:) Kawecka-Wyrzykowska E., Synowiec E. (red.): Unia Europejska, t. I, Instytut Koniunktur i Cen Handlu Zagranicznego, Warszawa 2004.

Wysokińska Z., Witkowska J.: Integracja Europejska. Dostosowania w Polsce w dziedzinie polityk, Polskie Wydawnictwo Ekonomiczne, Warszawa 2004.

ARDYKUŁY

Abramczyk S.: Polityka Ekologiczna Unii Europejskiej, Aura z 1997 r., nr 5.

Kociszewski K.: Rozwój zrównoważony (ekorozwój) - definicja, podstawowe pojęcia, zastosowania, Akademia Ekonomiczna we Wrocławiu,

RówNY K.: Koncepcja zrównoważonego rozwoju w prawie wspólnotowym i polskiej rzeczywistości (Zarys najważniejszych zagadnień wyjściowych), Przegląd Prawa Europejskiego z 2000 r., nr 2, s. $58-72$;

ŹRÓDŁA IN囚ERNE囚OWE

http://www.ecp.wroc.pl/msp/kociszewskil.pdf

\section{SUMMARY}

The intensive economic development within EU member countries leading to a significant environment pollution invoked in 70's a strong need to introduce uniform legal regulations of a common pro-ecological policy. Therefore, during the Conference in Paris in 1972, the European Commission was obliged to work out particular programs for the environment protection, realization of which was intended to be done in subsequent time intervals. Incorporation of the first two programs led to formulating principle rules of EU ecological policy that up till now are general determinant of environmental protection in Europe. As a result of the following two programs, a complex system of legal and financial protective instruments along with the system for environment screening was worked out. That time, also two important ecological rules were formulated: durability of natural capital, and ensuring the appropriate environment conditions for further generations. These rules are considered as a basis for sustainable development accepted as one of the main targets of EU ecological policy. The continuation of activities for sustainable development can be also found in subsequent programs (including the VI Program planned for realization by 2010) focused on the search for such legal and institutional solutions that would guarantee the equilibrium between the economic development of particular EU members and the improvement of environment status. Here performed analysis of programs for the environment protection allows for presenting not only the following stages of the ecological law formation in European Union but also underlining their role in shaping and realization of the sustainable development concept. 